\title{
Preparation of Polyfunctional Naphthyridines by Cobalt-Catalyzed Cross-Couplings of Halogenated Naphthyridines with Magnesium and Zinc Organometallics
}

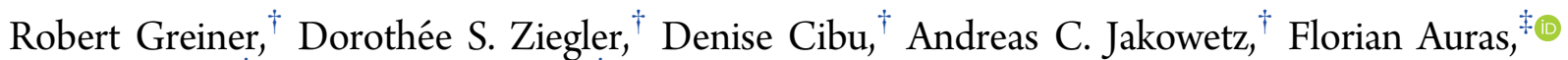

Thomas Bein, ${ }^{\dagger}$ and Paul Knochel ${ }^{*}{ }^{\dagger}$ (1)

${ }^{\dagger}$ Department of Chemistry, Ludwig-Maximilians-Universität, Butenandtstrasse 5-13, 81377 Munich, Germany

${ }^{\ddagger}$ Cavendish Laboratory, University of Cambridge, Cambridge CB3 0HE, United Kingdom

Supporting Information

ABSTRACT: $\mathrm{CoCl}_{2}(5 \%)$ catalyzes cross-couplings of various halogenated naphthyridines with alkyl- and arylmagnesium halides. Also, arylzinc halides undergo smooth cross-couplings with various naphthyridines in the presence of $\mathrm{CoCl}_{2} \cdot 2 \mathrm{LiCl}$ (5\%) and sodium formate (50\%), leading to polyfunctional arylated naphthyridines. Two of these arylated naphthyridines are highly fluorescent, with quantum efficiencies reaching $95 \%$ and long excited-state lifetimes of up to $12 \mathrm{~ns}$.

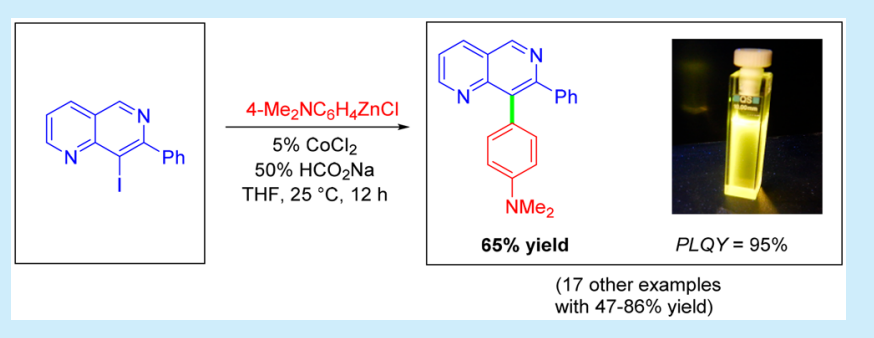

$\mathrm{N}$ -Heterocyclic scaffolds are ubiquitous building blocks for pharmaceuticals, agrochemicals, and materials science. ${ }^{1}$ There is a need for new $\mathrm{N}$-heterocyclic structures since novel ring systems may display original biological or physical properties. Recently, the naphthyridine scaffold has attracted increased attention. $^{2}$ Its functionalization was found to be especially difficult, and only a few methods are available. ${ }^{3}$ Although Fecatalyzed cross-couplings have been used to functionalize chloronaphthyridines, the scope of such cross-couplings is quite limited. ${ }^{4}$ Interestingly, Co-catalyzed cross-couplings generally display a broader reaction scope and have proved to be very useful for the functionalization of electron-deficient $\mathrm{N}$ heterocycles. ${ }^{5}$ We recently showed that the addition of appropriate ligands (e.g., sodium formate or pivalate) considerably extends the scope of these cross-couplings. ${ }^{6}$ Herein we report that Co-catalyzed cross-couplings allow efficient functionalization of various halogenated naphthyridines.

In preliminary experiments, we found that chloronaphthyridines $\mathbf{1 a}-\mathbf{c}$ are easily alkylated using $5 \% \mathrm{CoCl}_{2}$ in THF (Table 1 ). Thus, the reaction of 3,6-dichloro-1,8-dimethyl-2,7-naphthyridine (1a) with 2-phenylethylmagnesium bromide (2a) at 25 ${ }^{\circ} \mathrm{C}$ (30 min) provided monoalkylated naphthyridine 3a in $80 \%$ yield (Table 1, entry 1 ). Similarly, alkylmagnesium reagent 2 a allowed the conversion of 1-chloro-2,7-naphthyridine (1b) to the expected 1-phenethyl-2,7-naphthyridine (3b) in $82 \%$ yield (entry 2). Treatment of $\mathbf{1 b}$ with $\mathrm{MeMgCl}$ (2b) gave the corresponding 1-methyl-2,7-naphthyridine (3c) in $98 \%$ yield (entry 3). Furthermore, sec- $\mathrm{BuMgCl}$ (2c) underwent crosscoupling with $\mathbf{1 b}$ to afford 2,7-naphthyridine $3 \mathrm{~d}$ in $54 \%$ yield (entry 4). Co-catalyzed alkylation of 5-chloro-1,6-naphthyridine 1c with $\mathrm{BuMgCl}$ (2d) provided 1,6-naphthyridine 3e in 69\% yield (entry 5). Additionally, the reaction of 5-chloro-1,6- naphthyridine 1c with cyclopropylmagnesium bromide (2e) gave 1,6-naphthyridine $3 \mathrm{f}$ in $52 \%$ yield (entry 6).

Furthermore, we have found that 3,6-dichloronaphthyridine 1a was easily bisarylated in the presence of $5 \% \mathrm{CoCl}_{2}$ using arylmagnesium reagents ${ }^{7}$ such as $\mathbf{4 a}-\mathbf{d}$ (Scheme 1 ). Thus, the reaction of 1a with 4-trimethylsilylphenylmagnesium bromide (4a) (3.0 equiv) at $-40{ }^{\circ} \mathrm{C}$ provided bisarylated 2,7naphthyridine $5 \mathrm{a}$ in $62 \%$ yield within $4 \mathrm{~h}$. Similarly, 4-N,Ndimethylaminophenylmagnesium bromide (4b) and 4-anisylmagnesium bromide (4c) underwent Co-catalyzed crosscouplings $\left(-40^{\circ} \mathrm{C}, 4-12 \mathrm{~h}\right)$ with 1a, leading to 3,6-substituted naphthyridines $\mathbf{5 b}$ and $\mathbf{5 c}$, respectively, in 60-73\% yield. Sterically hindered mesitylmagnesium bromide (4d), however, reacted with 1 a at $25{ }^{\circ} \mathrm{C}$ within $4 \mathrm{~h}$, furnishing 2,7-naphthyridine

We noticed that $\mathrm{C}\left(\mathrm{sp}^{2}\right)-\mathrm{C}\left(\mathrm{sp}^{2}\right)$ cross-couplings of naphthyridines $\mathbf{1 b}$ and $\mathbf{1 c}$ with $\mathrm{PhMgCl}$ using $5 \% \mathrm{CoCl}_{2}$ led to low yields $(<30 \%)$. This problem could be solved by replacing arylmagnesium halides with the corresponding arylzinc reagents and using $\mathrm{HCO}_{2} \mathrm{Na}$ as a ligand. ${ }^{6 a}$ Thus, $\mathbf{1 b}$ reacted smoothly with $\mathrm{PhZnCl}(\mathbf{6 a})$ or $\left[1,1^{\prime}\right.$-biphenyl]-4-ylzinc chloride (6b) within 12 $\mathrm{h}$ at $25^{\circ} \mathrm{C}$, furnishing the corresponding arylated naphthyridines $7 \mathbf{a}$ and $7 \mathbf{b}$ in $80-82 \%$ yield (Table 2 , entries 1 and 2 ). Furthermore, a range of arylzinc reagents $6 c-f$ bearing various functional groups underwent such Co-catalyzed Negishi ${ }^{8}$ crosscouplings with $\mathbf{1 b}$, providing the expected products $7 \mathrm{c}-\mathrm{f}$ in $69-$ $79 \%$ yield (entries $3-6$ ). Heteroaryl-heteroaryl cross-couplings are utmost challenging because of catalyst deactivation when $\mathrm{Pd}$ or Ni catalysts are used. ${ }^{9}$ However, in the presence of THFsoluble $\mathrm{CoCl}_{2} \cdot 2 \mathrm{LiCl}(5 \%)$ and $\mathrm{HCO}_{2} \mathrm{Na}(50 \%)$, the cross-

Published: November 20, 2017 $5 \mathbf{d}$ in $93 \%$ yield.

Received: October 17, 2017 
Table 1. Co-Catalyzed Alkylation of Chloronaphthyridines 1a-c with Alkylmagnesium Reagents $2 a-e$

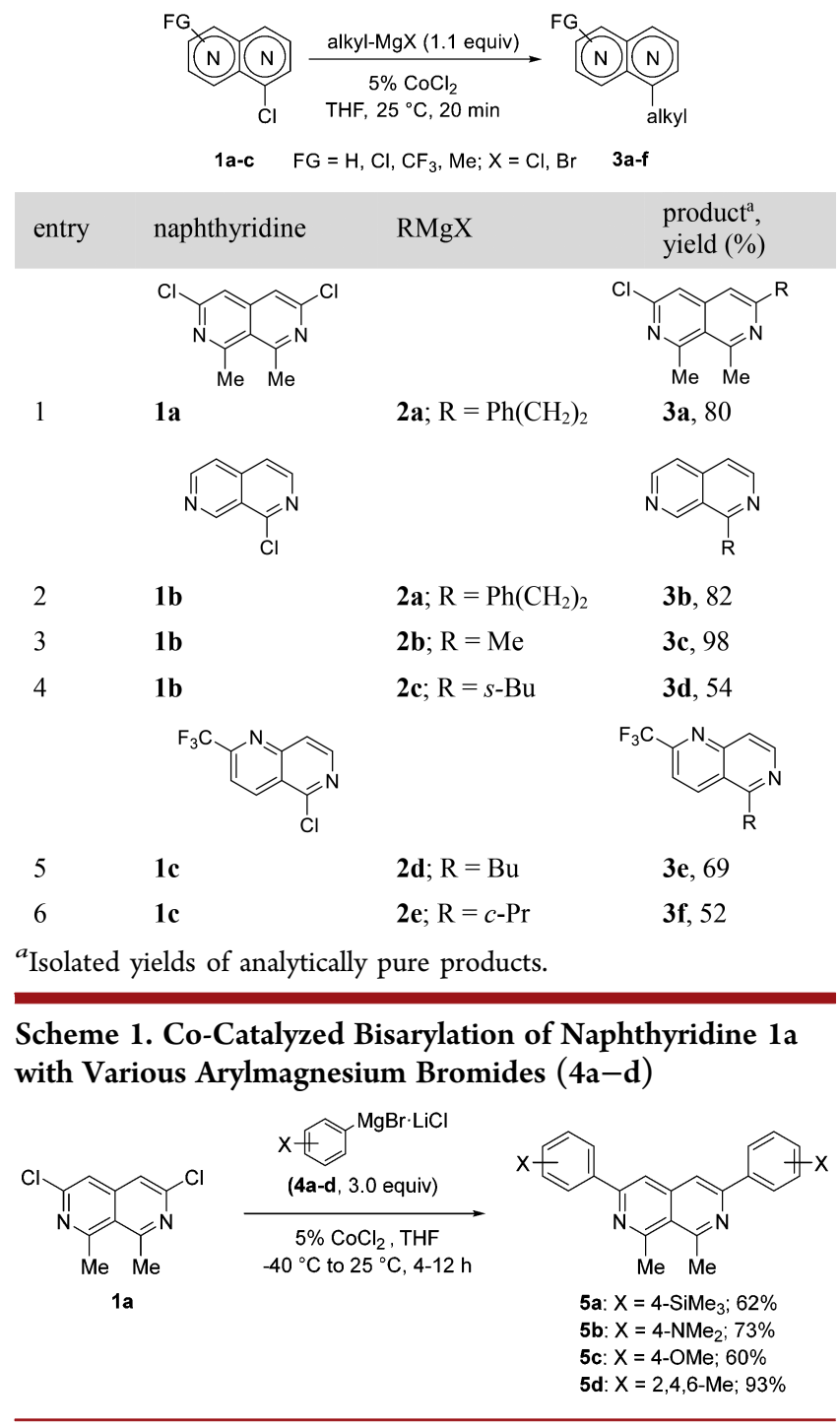

coupling of 1-chloronaphthyridine $\mathbf{1 b}$ with 2 -thienylzinc chloride $(6 \mathrm{~g})$ afforded 2,7-naphthyridine $7 \mathrm{~g}$ in $60 \%$ yield (entry 7 ). We further have shown that naphthyridine 1c was easily arylated under these conditions. Thus, the reaction of $1 \mathrm{c}$ with arylzinc chlorides $6 \mathbf{h}$ and $6 \mathbf{i}$ provided 1,6-naphthyridines $7 \mathbf{h}$ and $7 \mathbf{i}$, respectively, in $74-83 \%$ yield (entries 8 and 9 ). Interestingly, the Co-catalyzed arylation of 1c with 2-(triisopropylsilyloxy)phenylzinc chloride $(6 \mathbf{j})$ succeeded at only elevated temperature $\left(60{ }^{\circ} \mathrm{C}, 12 \mathrm{~h}\right)$ to give naphthyridyl alcohol derivative $7 \mathrm{j}$ in $61 \%$ yield (entry 10). Also, iodo-substituted naphthyridines were excellent substrates for such Co-catalyzed cross-couplings. Thus, the reaction of electron-rich arylzinc reagents $6 \mathbf{k}$ and $6 \mathbf{l}$ with 4iodo-1,5-naphthyridine (1d) afforded 1,5-naphthyridines $7 \mathbf{k}$ and 71 , respectively, in $78-80 \%$ yield (Table 3 , entries 1 and 2 ). Similarly, the reaction of electron-deficient $p-\mathrm{NCC}_{6} \mathrm{H}_{4} \mathrm{ZnCl}$ (6m) with $1 \mathrm{~d}$ led to naphthyridine $7 \mathrm{~m}$ in $83 \%$ yield (entry 3 ). Furthermore, heteroarylzinc reagent 6 n reacted smoothly with $\mathbf{1 d}$ to afford naphthyridine $\mathbf{7 n}$ in $73 \%$ yield (entry 4 ). Remarkably, sterically demanding naphthylzinc reagent 60 was also converted with $1 \mathrm{~d}$ to 1,5 -naphthyridine $7 \mathrm{o}$ in $47 \%$ yield (entry 5).
Table 2. Co-Catalyzed Arylations of Arylzinc Reagents 6a-j with Chloronaphthyridines $1 \mathrm{~b}$ and $1 \mathrm{c}$

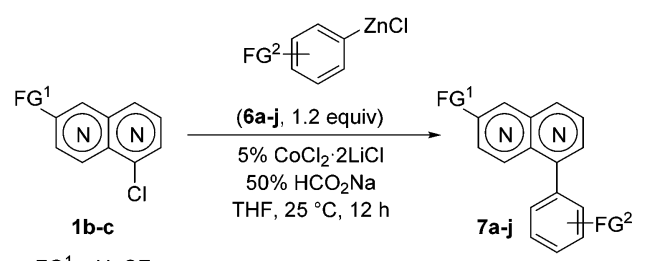

$\mathrm{FG}^{1}=\mathrm{H}, \mathrm{CF}_{3}$

$\mathrm{FG}^{2}=\mathrm{H}, \mathrm{OMe}$, OTBS, OTIPS, OBn, CN, F, CF $3, \mathrm{SMe}, \mathrm{Ph}, \mathrm{Me}$

entry $\begin{array}{ll}\text { zinc reagent } \\ 6\end{array}$

$6 \quad 1 \mathbf{b}$

6f

$7 \mathbf{f}, 79$
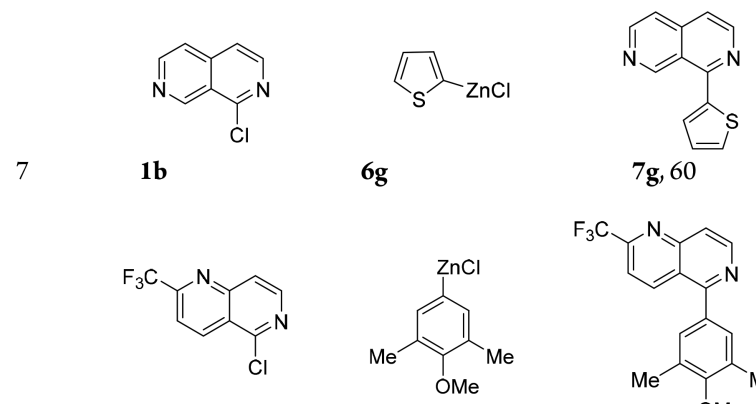

$7 \mathrm{~g}, 60$

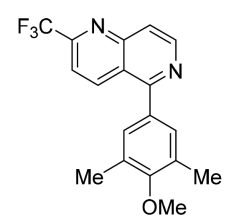

8

$1 c$

6h

$7 \mathbf{h}, 74$<smiles>FC(F)(F)c1ccc2c(Cl)nccc2n1</smiles><smiles>[X]c1ccccc1Cl</smiles><smiles>[X]c1cccc(-c2nccc3nc(C(F)(F)F)ccc23)c1</smiles>

$9 \quad \mathbf{1 c} \quad \mathbf{6 i} ; \mathrm{X}=p-\mathrm{OBn} \quad 7 \mathbf{i}, 83$

$10 \quad \mathbf{1 c} \quad \mathbf{6 j} ; \mathrm{X}=o$-OTIPS $\quad 7 \mathbf{j}, 61^{\mathrm{b}}$

${ }^{a}$ Isolated yields of analytically pure products. ${ }^{b}$ The cross-coupling reaction proceeded at $60{ }^{\circ} \mathrm{C}$ for $12 \mathrm{~h}$.

This mild method also allows the coupling of sensitive iodonaphthyridines. Thus, the coupling of zinc reagent $6 \mathrm{p}$ with 4-iodo-1,5-naphthyridine le provided the corresponding 4,8functionalized 1,5 -naphthyridine $7 \mathbf{p}$ in $86 \%$ yield (entry 6 ). Similarly to the bisarylation of dichloronaphthyridine 1a (Scheme 1), we also examined the Co-catalyzed reaction of 2,4-diiodo-1,5-naphthyridine (1f) with $p$ - $\mathrm{MeOC}_{6} \mathrm{H}_{4} \mathrm{ZnCl}$ (61) and obtained the corresponding bis(anisyl)naphthyridine $\mathbf{7 q}$ in $75 \%$ yield (entry 7 ). Finally, Co-catalyzed cross-coupling of 
Table 3. Co-Catalyzed Arylations of Arylzinc Reagents 6k and 61 with Iodonaphthyridines $1 \mathrm{~d}-\mathrm{g}$

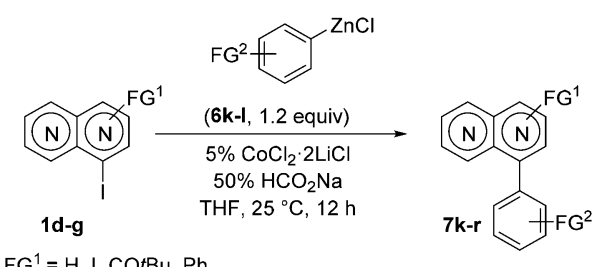

$\mathrm{FG}^{1}=\mathrm{H}, \mathrm{I}, \mathrm{COtBu}, \mathrm{Ph}$

$\mathrm{FG}^{2}=\mathrm{OMe}, \mathrm{SMe}, \mathrm{NMe}_{2}, \mathrm{CN}$

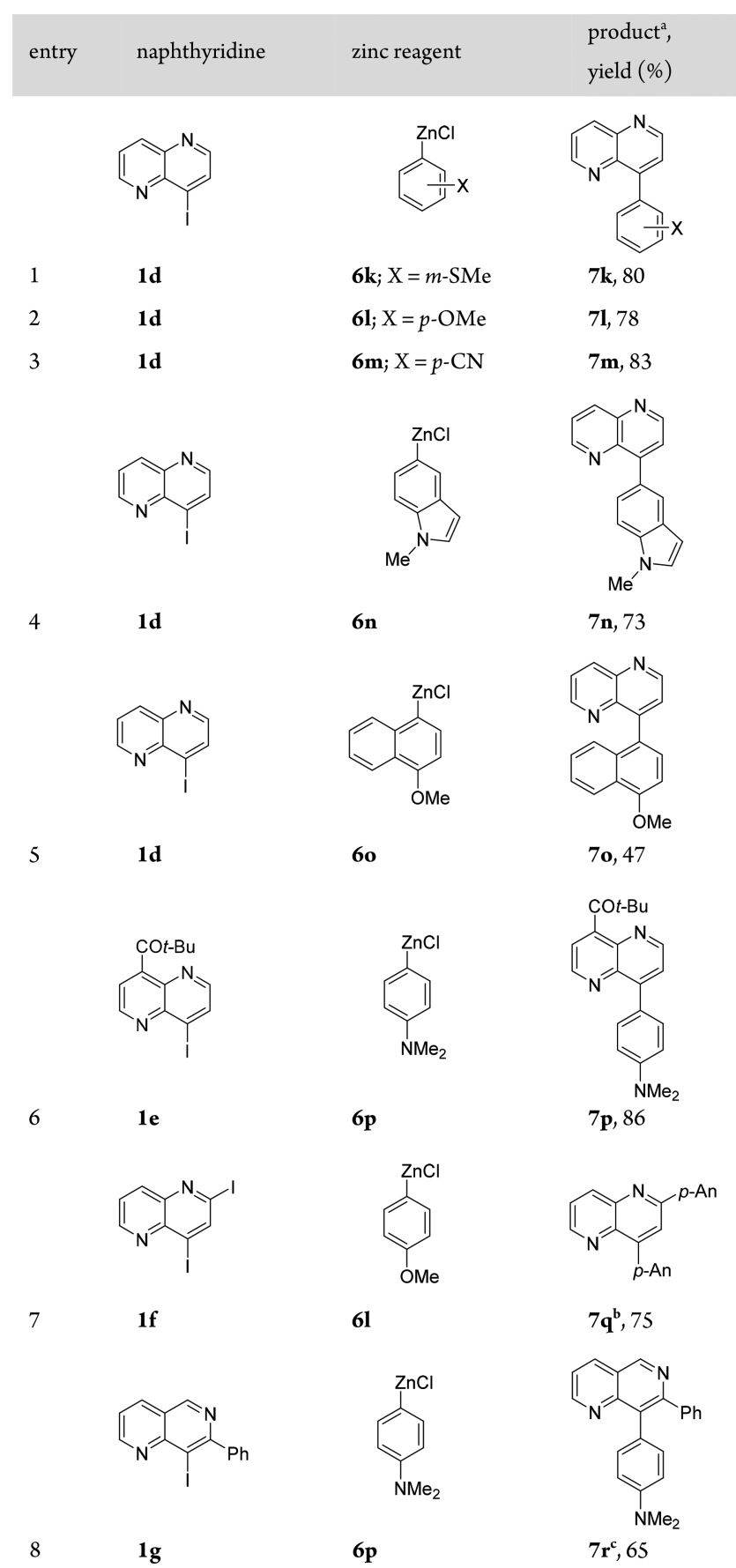

${ }^{a}$ Isolated yields of analytically pure products. ${ }^{b} 2.4$ equiv of zinc reagent was used. $p$ - $\mathrm{An}=p-\mathrm{MeOC}_{6} \mathrm{H}_{4} \cdot{ }^{c_{3}} 3.0$ equiv of the arylzinc reagent was necessary for complete conversion.

sterically hindered 8-iodo-1,6-naphthyridine $(\mathbf{1 g})^{10}$ with $p$ $\mathrm{Me}_{2} \mathrm{NC}_{6} \mathrm{H}_{4} \mathrm{ZnCl}(6 \mathbf{p})$ furnished naphthyridine $7 \mathbf{r}$ in $65 \%$ yield (entry 8 ). We also found that $\mathbf{1 d}$ smoothly reacts with benzylic zinc reagents. ${ }^{11}$ Thus, the couplings of $\mathbf{1 d}$ with benzylzinc chlorides $8 \mathbf{a}$ and $\mathbf{8 b}$ provided 1,5-naphthyridines $\mathbf{9 a}$ and $\mathbf{9 b}$ in $62-75 \%$ yield (Scheme 2 ).

Scheme 2. Co-Catalyzed Cross-Coupling of 4-Iodo-1,5naphthyridine (1d) with Benzylic Zinc Reagents 8a and $8 b$

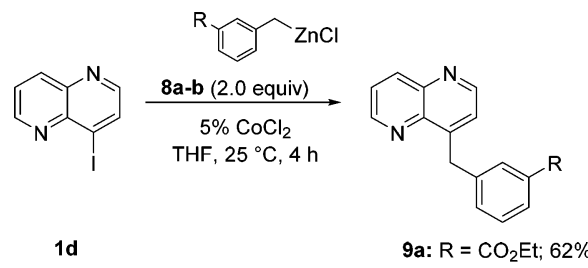

9b: $R=F ; 75 \%$

By using mixed halogenated naphthyridines, we observed that 1-chloro-4-iodo-2,7-naphthyridine (10) was regioselectively functionalized by stepwise cross-coupling utilizing successive $\mathrm{Pd}$ and Co catalyses (Scheme 3). Thus, Pd-catalyzed Negishi

Scheme 3. Regioselective Pd/Co-Catalyzed Cross-Coupling

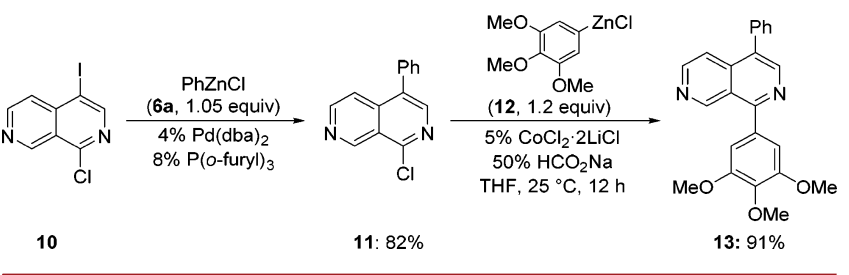

cross-coupling of 10 with $\mathrm{PhZnCl}$ (6a) selectively furnished 2,7naphthyridine 11 in $82 \%$ yield. Subsequent Co-catalyzed crosscoupling with arylzinc chloride $\mathbf{1 2}$ gave the mixed bisarylated naphthyridine 13 in $91 \%$ yield.

Naphthyridine derivatives have previously been applied as fluorescent probes $^{12}$ or as ligands for fluorescent complexes. ${ }^{13}$ The newly prepared naphthyridines $\mathbf{5 b}$ and $7 \mathbf{r}$ are highly fluorescent in various organic solvents and display strong solvatochromism (Figure $1 \mathrm{a}, \mathrm{b}$ and Supporting Information (SI) Figures 1-4). We suggest that these phenomena are based on strong interactions between the electron donor $\mathrm{NMe}_{2}$ and the electron-poor naphthyridine moiety as an electron acceptor. While the absolute photoluminescence quantum efficiencies (PLQEs) of $\mathbf{5 b}$ in various solvents are about $20 \%$, the PLQE of $7 \mathbf{r}$ is almost quantitative in nonpolar solvents (toluene, $95 \pm 5 \%$; cyclohexane, $93 \pm 5 \%$ ) and drops only slightly in more polar solvents $\left(\mathrm{CHCl}_{3}, 81 \pm 5 \%\right.$; 1,4-dioxane, 80 $\pm 5 \%$; THF, $71 \pm 5 \%$; see SI Figures 5 and 6 for details). These high emission efficiencies are accompanied by very long excited lifetimes of 3.8 and $12.0 \mathrm{~ns}$ for $\mathbf{5 b}$ and $\mathbf{7 r}$, respectively (Figure $1 \mathrm{c}, \mathrm{d}$; see the SI for details).

In summary, we have prepared various novel polyfunctionalized naphthyridines by Co-catalyzed cross-couplings. Alkyl- and arylmagnesium reagents reacted smoothly with chloro-2,7naphthyridines using $\mathrm{CoCl}_{2}(5 \%)$. The addition of sodium formate allowed an extension of the range of functionalized $\mathrm{N}$ heterocycles by mild cross-coupling of chloro- and iodonaphthyridines with arylzinc reagents. Two of the new naphthyridines are highly fluorescent (PLQE $=20-95 \%$ ) with tunable emission from blue to yellow and long excited-state lifetimes from 3.8 to 12.0 ns. Further extensions of organometallic naphthyridine functionalizations are currently underway in our laboratories. 

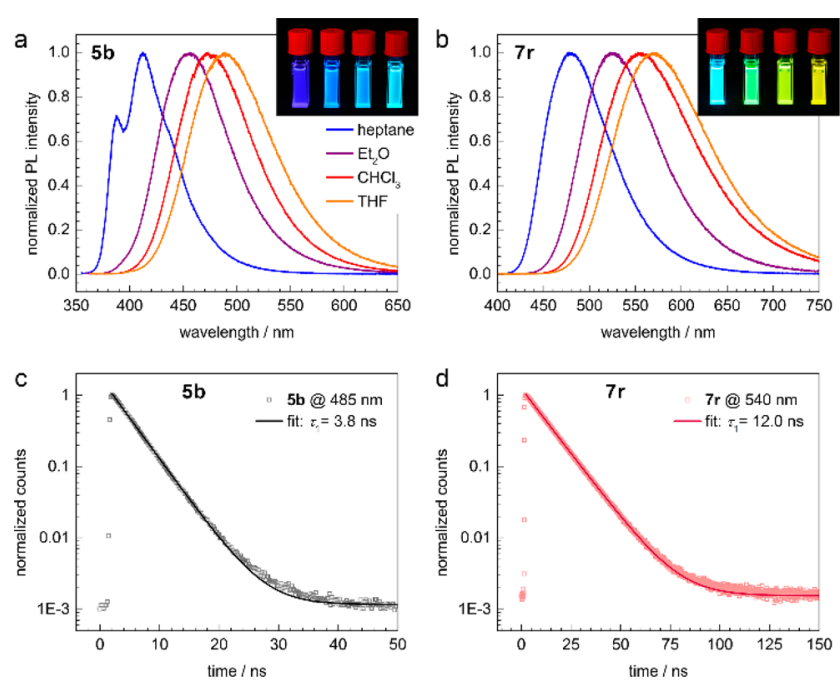

Figure 1. (a, b) PL spectra of compounds $5 \mathbf{b}$ and $7 \mathbf{r}$, respectively, dissolved in heptane (blue), $\mathrm{Et}_{2} \mathrm{O}$ (purple), $\mathrm{CHCl}_{3}$ (red), and THF (orange). The excitation wavelengths were 360 and $390 \mathrm{~nm}$, respectively. The insets show photographs of the solutions under UV illumination. (c, d) Time-correlated single-photon counting (TCSPC) traces of $\mathbf{5 b}$ and $7 \mathbf{r}$ in $\mathrm{CHCl}_{3}$, measured at the peaks of the PL spectra (open symbols). The solid lines are monoexponential fits.

\section{ASSOCIATED CONTENT}

\section{S Supporting Information}

The Supporting Information is available free of charge on the ACS Publications website at DOI: 10.1021/acs.orglett.7b03242.

Experimental details, GC data, melting points, and IR, ${ }^{1} \mathrm{H}$ and ${ }^{13} \mathrm{C}$ NMR, and mass spectra (PDF)

\section{AUTHOR INFORMATION}

\section{Corresponding Author}

*E-mail: paul.knochel@cup.uni-muenchen.de.

\section{ORCID 1}

Florian Auras: 0000-0003-1709-4384

Paul Knochel: 0000-0001-7913-4332

Notes

The authors declare no competing financial interest.

\section{ACKNOWLEDGMENTS}

We thank the DFG for financial support and Albemarle (Frankfurt) and BASF (Ludwigshafen) for gifts of chemicals.

\section{REFERENCES}

(1) (a) Snieckus, V. Chem. Rev. 1990, 90, 879. (b) Chinchilla, R.; Nájera, C.; Yus, M. Chem. Rev. 2004, 104, 2667. (c) Modern Heterocyclic Chemistry; Alvarez-Builla, J., Vaquero, J. J., Barluenga, J., Eds.; WileyVCH: Weinheim, Germany, 2011. (d) Vo, C.-V. T.; Bode, J. W. J. Org. Chem. 2014, 79, 2809.

(2) (a) Zhang, J.; Chen, F.; He, Y.-M.; Fan, Q.-H. Angew. Chem., Int. Ed. 2015, 54, 4622. (b) Chen, F.; Surkus, A. E.; He, L.; Pohl, M.-M.; Radnik, J.; Topf, C.; Junge, K.; Beller, M. J. Am. Chem. Soc. 2015, 137, 11718. (c) Shen, Z.-L.; Dhayalan, V.; Benischke, A. D.; Greiner, R.; Karaghiosoff, K.; Mayer, P.; Knochel, P. Angew. Chem., Int. Ed. 2016, 55, 5332. (d) Fernandez, S.; Ganiek, M. A.; Karpacheva, M.; Hanusch, F. C.; Reuter, S.; Bein, T.; Auras, F.; Knochel, P. Org. Lett. 2016, 18, 3158. (e) Ma, W.; Chen, F.; Liu, Y.; He, M.-Y.; Fan, Q.-H. Org. Lett. 2016, 18, 2730. (f) Jackl, M. K.; Kreituss, I.; Bode, J. W. Org. Lett. 2016, 18, 1713. (g) Xiong, B.; Zhang, S.; Jiang, H.; Zhang, M. Org. Lett. 2016, 18, 724. (h) Zhang, S.-L.; Deng, Z.-Q. Org. Biomol. Chem. 2016, 14, 8966.

(3) (a) Voight, E. A.; Yin, H.; Downing, S. V.; Calad, S. A.; Matsuhashi, H.; Giordano, I.; Goodman, R. M.; Hennessy, A. J.; Wood, J. L. Org. Lett. 2010, 12, 3422. (b) Plodek, A.; König, M.; Bracher, F. Eur. J. Org. Chem. 2015, 1302. (c) Balkenhohl, M.; Greiner, R.; Makarov, I. S.; Heinz, B.; Karaghiosoff, K.; Zipse, H.; Knochel, P. Chem. - Eur. J. 2017, 23, 13046. (d) Ziegler, D. S.; Greiner, R; Lumpe, H.; Kqiku, L.; Karaghiosoff, K.; Knochel, P. Org. Lett. 2017, 19, 5760.

(4) Greiner, R.; Blanc, R.; Petermayer, C.; Karaghiosoff, K.; Knochel, P. Synlett 2016, 27, 231.

(5) For recent Co-catalyzed cross-coupling reactions, see: (a) Ohmiya, H.; Yorimitsu, H.; Oshima, K. J. Am. Chem. Soc. 2006, 128, 1886. (b) Ohmiya, H.; Yorimitsu, H.; Oshima, K. Org. Lett. 2006, 8, 3093.

(c) Bégouin, J.-M.; Gosmini, C. J. Org. Chem. 2009, 74, 3221. (d) Bégouin, J.-M.; Rivard, M.; Gosmini, C. Chem. Commun. 2010, 46, 5972. (e) Nicolas, L.; Angibaud, P.; Stansfield, I.; Bonnet, P.; Meerpoel, L.; Reymond, S.; Cossy, J. Angew. Chem., Int. Ed. 2012, 51, 11101. (f) Hammann, J. M.; Haas, D.; Knochel, P. Angew. Chem., Int. Ed. 2015, 54, 4478. (g) Kuzmina, O. M.; Steib, A. K.; Fernandez, S.; Boudot, W.; Markiewicz, J. T.; Knochel, P. Chem. - Eur. J. 2015, 21, 8242.

(6) (a) Haas, D.; Hammann, J. M.; Lutter, F. H.; Knochel, P. Angew. Chem., Int. Ed. 2016, 55, 3809. (b) Hofmayer, M. S.; Hammann, J. M.; Lutter, F. H.; Knochel, P. Synthesis 2017, 49, 3925. (c) Hammann, J. M.; Lutter, F. H.; Haas, D.; Knochel, P. Angew. Chem., Int. Ed. 2017, 56, 1082.

(7) Piller, F. M.; Appukkuttan, P.; Gavryushin, A.; Helm, M.; Knochel, P. Angew. Chem., Int. Ed. 2008, 47, 6802.

(8) For recent transition-metal-catalyzed Negishi cross-coupling reactions, see: (a) Avedissian, H.; Bérillon, L.; Cahiez, G.; Knochel, P. Tetrahedron Lett. 1998, 39, 6163. (b) Hossain, K. M.; Takagi, K. Chem. Lett. 1999, 28, 1241. (c) Zhou, J.; Fu, G. C. J. Am. Chem. Soc. 2003, 125, 12527. (d) Nakamura, M.; Ito, S.; Matsuo, K.; Nakamura, E. Synlett 2005, 1794. (e) Organ, M. G.; Avola, S.; Dubovyk, I.; Hadei, N.; Kantchev, E. A. B.; O’Brien, C. J.; Valente, C. Chem. - Eur. J. 2006, 12, 4749. (f) Takahashi, H.; Inagaki, S.; Yoshii, N.; Gao, F.; Nishihara, Y.; Takagi, K. J. Org. Chem. 2009, 74, 2794. (g) Bedford, R. B.; Huwe, M.; Wilkinson, M. C. Chem. Commun. 2009, 600. (h) Ejiri, S.; Odo, S.; Takahashi, H.; Nishimura, Y.; Gotoh, K.; Nishihara, Y.; Takagi, K. Org. Lett. 2010, 12, 1692. (i) Smith, A. L.; Hardcastle, K. I.; Soper, J. D. J. Am. Chem. Soc. 2010, 132, 14358. (j) Kealey, S.; Passchier, J.; Huiban, M. Chem. Commun. 2013, 49, 11326. (k) Haas, D.; Hammann, J.; Greiner, R; Knochel, P. ACS Catal. 2016, 6, 1540.

(9) (a) Kaes, C.; Katz, A.; Hosseini, M. W. Chem. Rev. 2000, 100, 3553. (b) Bedel, S.; Ulrich, G.; Picard, C.; Tisnès, P. Synthesis 2002, 1564. (c) Comprehensive Coordination Chemistry II, Vol. 1; McCleverty, J. A., Meyer, T. J., Eds.; Elsevier: Oxford, U.K., 2004. (d) Düfert, M. A.; Billingsley, K. L.; Buchwald, S. L. J. Am. Chem. Soc. 2013, 135, 12877.

(10) Huang, Q.; Hunter, J. A.; Larock, R. C. Org. Lett. 2001, 3, 2973.

(11) (a) Metzger, A.; Schade, M. A.; Knochel, P. Org. Lett. 2008, 10, 1107. (b) Bedford, R. B.; Huwe, M.; Wilkinson, M. C. Chem. Commun. 2009, 600. (c) Bégouin, J.-M.; Claudel, S.; Gosmini, C. Synlett 2009, 3192. (d) Cai, Y.; Benischke, A. D.; Knochel, P.; Gosmini, C. Chem. Eur. J. 2017, 23, 250.

(12) (a) Sun, Y.-Y.; Liao, J.-H.; Fang, J.-M.; Chou, P.-T.; Shen, C.-H.; Hsu, C.-W.; Chen, L.-C. Org. Lett. 2006, 8, 3713. (b) Andrew, T. L.; VanVeller, B.; Swager, T. M. Synlett 2010, 3045. (c) Wang, K.-Y.; Chen, C.; Liu, J.-F.; Wang, Q.; Chang, J.; Zhu, H.-J.; Li, C. Org. Biomol. Chem. 2012, 10, 6693. (d) Xiao, L.; Xing, X.; Chen, Z.; Qu, B.; Lan, H.; Gong, Q.; Kido, J. Adv. Funct. Mater. 2013, 23, 1323.

(13) (a) Liao, J.-H.; Chen, C.-T.; Chou, H.-C.; Cheng, C.-C.; Chou, P.T.; Fang, J.-M.; Slanina, Z.; Chow, T. J. Org. Lett. 2002, 4, 3107. (b) Li, H.-J.; Fu, W.-F.; Li, L.; Gan, X.; Mu, W.-H.; Chen, W.-Q.; Duan, X.-M.; Song, H.-B. Org. Lett. 2010, 12, 2924. (c) Liu, S.-W.; Lee, C.-C.; Lin, C.F.; Huang, J.-C.; Chen, C.-T.; Lee, J.-H. J. Mater. Chem. 2010, 20, 7800. (d) Wu, Y.-Y.; Chen, Y.; Gou, G.-Z.; Mu, W.-H.; Lv, X.-J.; Du, M.-L.; Fu, W.-F. Org. Lett. 2012, 14, 5226. (e) Krämer, C.; Leingang, S.; Hübner, O.; Kaifer, E.; Wadepohl, H.; Himmel, H.-J. Dalton Trans. 2016, 45, 16966. 